\title{
The Differentiation of Excitability in Embryonic Chick Limb Motoneurons
}

\author{
David P. McCobb, ${ }^{1}$ Phillip M. Best, ${ }^{2}$ and Kurt G. Beam ${ }^{1}$ \\ 'Department of Physiology, Colorado State University, Fort Collins, Colorado, 80523, and ${ }^{2}$ Department of Physiology and \\ Biophysics, University of Illinois, Urbana, Illinois 61801
}

\begin{abstract}
The well-documented role of neuromuscular activity as a regulator of motoneuron and muscle development raises important questions about the differentiation of excitability in motoneurons. We have recently described changes in expression of voltage-dependent calcium currents that take place during neuromuscular development in the chick embryo (McCobb et al., 1989). We now report similar analyses, using whole-cell patch-recording methods, of the major currents underlying action potential generation in the same motoneurons. Studies were conducted on identified hindlimb motoneurons isolated from the spinal cord at 3 very different stages of chick hindlimb development. Motoneurons could generate overshooting action potentials at the earliest stage studied [embryonic day 4 (E4)]. However, large changes in densities of several voltage-dependent ionic currents occurred thereafter. E6 and E11 motoneurons had progressively larger $I_{\mathrm{Na}}$ densities and, consequently, greater action potential amplitudes. Densities of 2 potassium currents, $I_{K}$ and $I_{A}$, increased on separate schedules. The relatively late and much larger increase in $I_{\mathrm{A}}$ resulted in a substantial developmental decline in action potential duration. These changes, which will greatly affect motoneuron output to muscle by affecting $\mathrm{Ca}^{2+}$ entry through voltage-gated channels, occur at the same time that activity-dependent developmental changes occur in the neuromuscular system.
\end{abstract}

The development of excitability appears, for at least some cells, to be a complex progression of events, as various voltage-dependent ionic currents that underlie specific features of excitability develop on independent schedules (Salkoff and Wyman, 1981; Bader et al., 1983, 1985; Barish, 1986; Nerbonne et al., 1986; Krieger and Sears, 1988; O'Dowd et al., 1988; McCobb et al., 1989; Nerbonne and Gurney, 1989). Such complexity raises many questions. For example, is the expression of various ion channel genes under differential control, and if so, what is the nature of the respective regulatory variables? Furthermore, because functional activity itself regulates many "downstream" features of nervous system development, can specific ionic currents be identified that play deciding roles in regulating the

\footnotetext{
Received Jan. 9, 1990; revised Apr. 24, 1990; accepted Apr. 25, 1990.

This research was supported by NIH Grants NS-26416 to K.G.B. and AR32062 to P.M.B., as well as individual NIII Postdoctoral Fellowship NS-08373 to D.P.M. K.G.B. was the recipient of NIH Research Career Development Award NS-01190.

Correspondence should be addressed to Dr. David P. McCobb, Department of Physiology, Colorado State University, Fort Collins, CO 80523.

Copyright $@ 1990$ Society for Neuroscience $0270-6474 / 90 / 092974-11 \$ 03.00 / 0$
}

expression of other genes that shape the nervous system? Obviously, specific hypotheses arc nceded to address these ideas. In the interest of framing such hypotheses, we have used patchclamp techniques to characterize excitability in an important developmental model.

Both synaptic and developmental interactions between vertebrate somatic motoneurons and their target muscle have been studied extensively. These studies document the importance of (1) trophic interactions, and (2) muscle activity as regulators of many aspects of both nerve and muscle phenotype during development and regeneration (Dennis, 1981; Brown, 1984; Betz, 1987; Purves, 1988). How motoneuron excitability might fit into the regulatory schemes is unknown. However, aspects of motoneuron phenotype, such as cell death (Laing and Prestige, 1978; Pittman and Oppenheim, 1978, 1979), axon terminal growth and branching (Dahm and Landmesser, 1988), and elimination of extraneous synapses (Srihari and Vrbová, 1978; Ding ct al., 1983), are potentially subject to influence by motoneuron activity both directly, as activity alters intracellular calcium levels, and indirectly, as motoneuron output limits muscle contractile activity.

Mature motoneurons and late immature motoneurons have been subjected to a wide variety of electrophysiological recording procedures (Barrett et al,, 1980; Mallart, 1984; Schwindt and Crill, 1984; Fulton and Walton, 1986; Ziskind-Conhaim, 1988). However, early motoneurons have only become accessible as retrograde labeling has been combined with patch-clamp recording from dissociated cells (O'Brien and Fischbach, 1986a, b, c, d; Fruns et al., 1987; McCobb et al., 1989). Whole-cell patch-clamp recording, because of the tight seal of electrode to the membrane and low-access resistance to the cell interior (Hamill et al., 1981; Sakmann and Neher, 1984), enable resolution and quantification of voltage-gated currents that are superior to those possible with techniques applied previously even to mature motoneurons. The purpose of the present study was to apply this technique to motoneurons isolated from as wide a span of neuromuscular system development as possible, allowing the identification of changes that take place during development in vivo.

The earliest age studied was embryonic day 4 (E4, stages 2224; Hamburger and IIamilton, 1951), which is soon after motoneuronal axons begin to grow out into the largely undifferentiated mesenchyme of the early limb buds, making them amenable to retrograde labeling (Fig. 1). The most dramatic phase of limb differentiation occurs before E11 (stage 37). By this point, the leg is much larger, is virtually mature in form, has contractile muscle and functional synapses, and is spontaneous- 
E4

\section{E6}

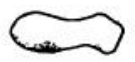

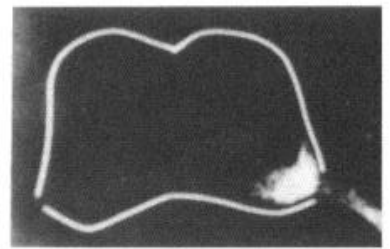
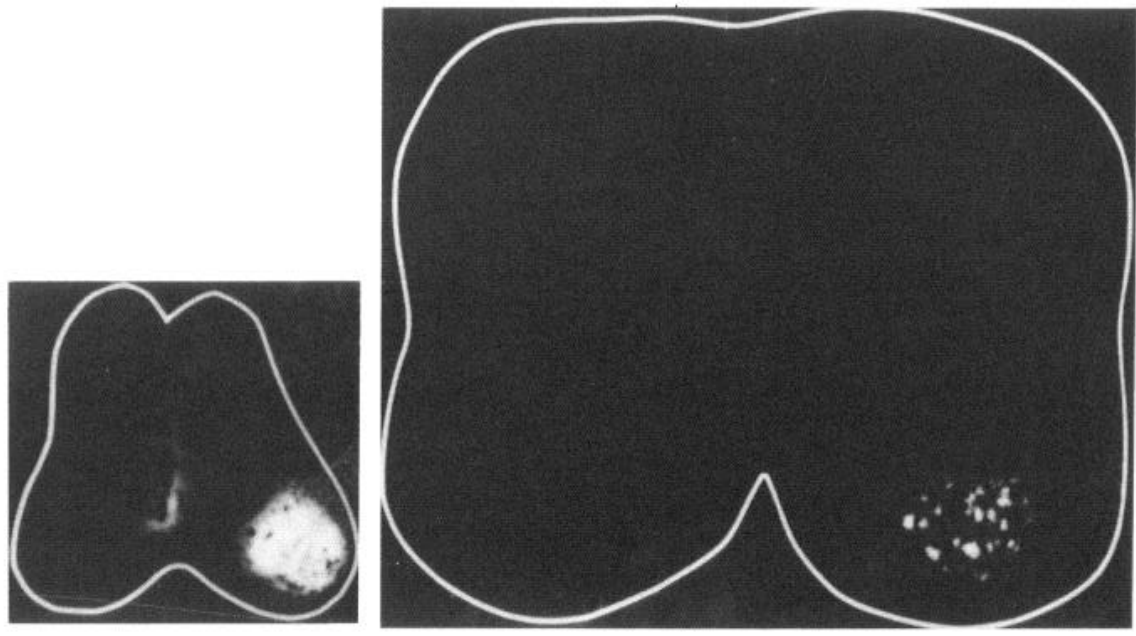

Figure 1. Retrograde labeling of chick hindlimb motoneurons with fluorescent DiI over the wide span of limb development studied. Line drawings illustrate limb size and shape at E4, E6, and E11 (stages 24, 29, and 37; Hamburger and Hamilton, 1951). Photographs are of fluorescence-illuminated cryostat sections of spinal cords of embryos at the same stages as seen in the line drawings (for clarity, the margins of the cords have been traced). DiI labeling was restricted to the lateral motor column region on the same side as the injected limb. E6 and E11 cords were dissected out before processing, but the E4 cord was fixed and sectioned within the embryo. The ventral root with labeled motor axons can be seen leading out of the right side of the E4 cord.

ly active (Hamburger, 1977; Jacobson, 1978). A relatively discrete phase of cell death, during which the motoneuron pool is reduced by $\sim 50 \%$, occurs between E6 and E9 (Hamburger, 1975; Laing, 1982) and is therefore bracketed by our measurements at E6 and E11. We previously reported that large changes in the expression of voltage-dependent $\mathrm{Ca}^{2+}$ currents occur in these motoneurons between E4 and E11 (McCobb et al., 1989), and we now report that the action potential mechanism and major underlying currents are undergoing equally important changes.

\section{Materials and Methods}

Retrograde labeling of limb motoneurons with the carbocyanine dye DiI. Embryonic chick limb motoneurons were retrogradely labeled in ovo with 1,1'-dioctadecyl-3,3,3',3'-tetramethylindocarbocyanine perchlorate (DiI) (Molecular Probes, Junction City, OR), with some modification of the procedure previously described (McCobb et al., 1989; see also Honig and Hume, 1986). Beginning on the morning of embryonic day 0 (E0), fertile eggs were incubated at $36-37^{\circ} \mathrm{C}$. Dye injections were made on the evening of E3, E5, or E10, and spinal cord dissociations were done the following morning (i.e., E4, E6, or E11). For injection, a hole was made in the shell over the air space, and the shell membrane was torn carefully away from extraembryonic membranes to avoid rupturing blood vessels. Forceps were used to tear a hole in the amnion of E4 and E6 embryos. A glass micropipet (a patch electrode with a broken tip) was used for dye injections into E4 and E6 embryonic limbs. The micropipet was mounted on an empty $10-\mathrm{ml}$ syringe, which supplied air pressure for ejecting the dye. In E11 embryos, the amnion was penetrated with the point of a pair of forceps; a hindlimb was then grasped at the foot and pulled through the hole, and muscles of the thigh and foreleg were injected through a 30-gauge needle with Dil suspended in saline and ethanol. Dye injection was done only into hindlimbs, thus minimizing the diversity of developmental stages in the motoneurons that would result from the rostrocaudal progression of spinal cord development. Eggs were sealed with plastic tape and returned to the in- cubator overnight. DiI was dissolved in $100 \%$ ethanol at $5 \mathrm{mg} / \mathrm{ml}$. This solution was then diluted with 4 times as much of a standard saline solution (composition of solutions given below) containing $0.1 \%$ bovine serum albumin, yielding a fine suspension of DiI $(1 \mathrm{mg} / \mathrm{ml})$ in $20 \%$ ethanol and $80 \%$ saline.

Embryos were staged according to Hamburger and Hamilton (1951). E4 embryos were at stages 22-24, E6 embryos at stages 28-29, and E11 embryos at stage 37 . To verify the selective labeling of neuronal somata in the lateral motor column region, cords from each stage were fixed in $2 \%$ paraformaldehyde, cryoprotected in a graded sucrose series, and cryostat-sectioned. As seen in Figure 1, fluorescent labeling was restricted to the ventrolateral region of the ipsilateral cord.

Spinal cord dissociation and motoneuron culture. The procedures used for obtaining limb motoneurons from E4, E6, and E11 embryos were slightly modified from those described in detail by McCobb et al. (1989). Dissections were made in saline. The spinal cords of staged embryos with dye-injected limbs were ventrally exposed. Tungsten needles were used to sever spinal nerve roots; the meninges were then stripped off, and the cord was transferred to $\mathrm{Ca}^{2+}$ - and $\mathrm{Mg}^{2+}$-free saline (CMFS) at room temperature. E6 and E11 cords were immediately cut into approximately $1-\mathrm{mm}^{3}$ pieces and transferred to a dram vial. E4 spinal cords were transferred intact. CMFS was replaced with trypsin solution, and the tissue was incubated at $37^{\circ} \mathrm{C}$ with gentle agitation for the appropriate length of time. E4 embryos were incubated in $0.05 \%$ trypsin (Sigma type XI) for $10 \mathrm{~min}$, E6 embryos were incubated in $0.1 \%$ for 20 $\mathrm{min}$, and E11 embryos were incubated in $0.40 \%$ for $45-60 \mathrm{~min}$. All trypsin solutions were made in CMFS. Tissue was rinsed and triturated in motoneuron plating medium (MnP), which lacks embryo extract, that was preincubated in the tissue culture incubator $\left(37^{\circ} \mathrm{C}, 5 \% \mathrm{CO}_{2}\right)$. A series of increasingly smaller-tipped fire-polished Pasteur pipets was used for trituration. Success was evidenced by translucent cell bodies and the retention of long stumps of broken processes on acutely dissociated neurons (Fig. 2). Neurons were plated in $35-\mathrm{mm}$ dishes or rectangular perfusion chambers $(1 \times 4 \mathrm{~cm})$. The substratum was coated before neuron plating with a thin layer of Matrigel (Collaborative Research Inc., Bedford, MA). MnP was replaced with motoneuron nutrient medium $(\mathrm{MnN})$, which contains embryo extract, $1-2 \mathrm{hr}$ after plating, 

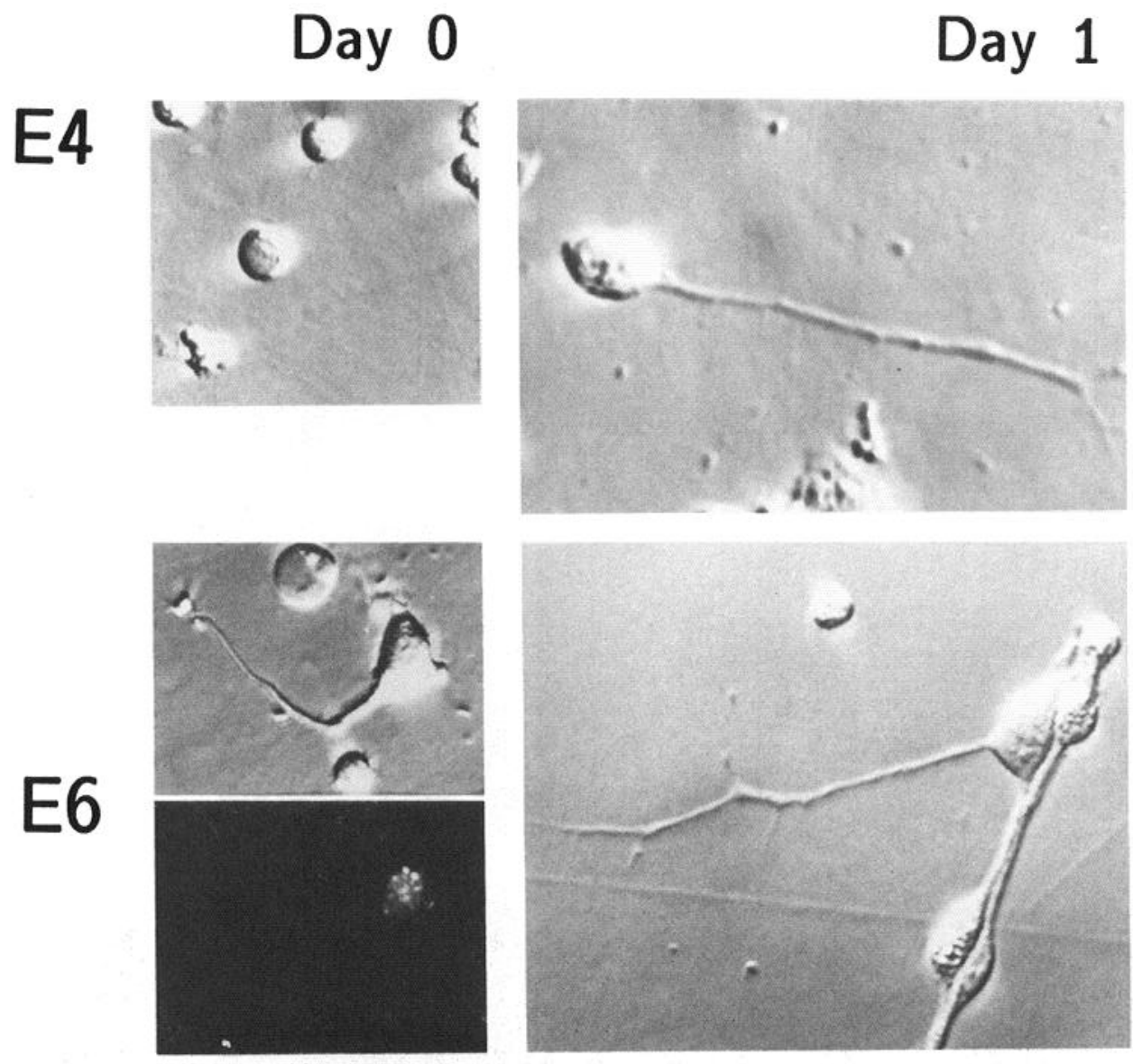

Figure 2. Identified chick limb motoneurons in cell culture viewed with Hoffman modulation contrast optics. Left, Acutely isolated motoneurons from E4 (stage 24), E6 (stage 29), and E11 (stage 37) embryos. Stumps of broken axons and dendrites are typically seen on E6 and E11 motoneurons but are not always obvious on E4 motoneurons. A fluorescence micrograph of the E6 motoneuron showing DiI labeling appears just below the Hoffman micrograph. Right, Motoneurons representing the same embryonic stages photographed on the day following isolation. Inset on the E11 motoneuron illustrates DiI fluorescence of the cell body. Filters for rhodamine dyes were used to visualize DiI. Scale bar, $50 \mu \mathrm{m}$
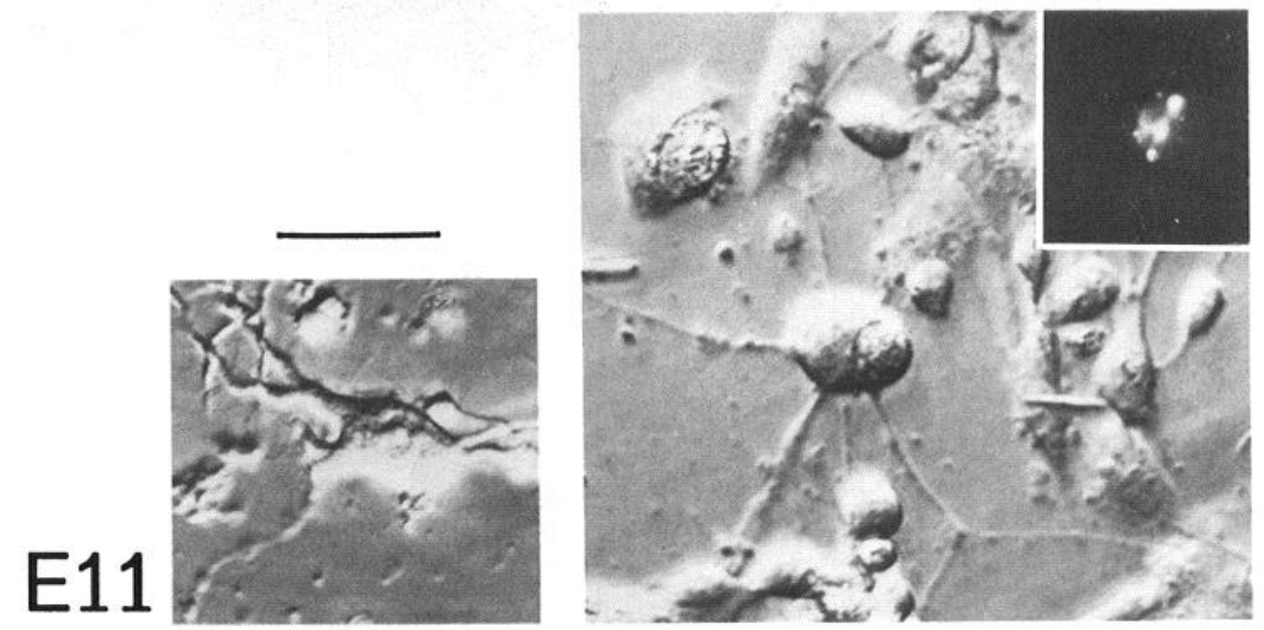

and cultures were left in the incubator overnight for electrophysiological analysis on the day following dissociation (Fig. 2). Both visual inspection and cell capacitance measurements indicated an increase in motoneuron size with development. Mean capacitance values for E4, E6, and E11 motoneurons were $18.6 \pm 0.7,26.4 \pm 0.9$, and $31.8 \pm 2.0$, respectively (mean $\pm \mathrm{SEM} ; n=50,50$, and 51 neurons). For comparisons between stages (as described below), ionic currents were expressed as current densities, obtained by dividing current amplitudes by cell capacitance. Within age groups, no correlation was found between current density and cell capacitance, suggesting that cell size per se did not confound the measurement of current density.

Electrophysiological recording. Motoneurons identified by fluorescence were studied using conventional whole-cell patch-clamp recording techniques. Patch electrodes were pulled from capillary glass and had resistances from 2.5 to $5 \mathrm{M} \Omega$ when filled with internal solution. Pipets were coated with wax to minimize electrode capacitance. A List L/M EPC-7 patch-clamp amplifier was used. After rupture of the patch to produce whole-cell voltage-clamp mode, pipet series resistance and linear capacitance of the cell membrane were calculated from the time constant of, and area beneath, the capacitive transient obtained during control pulses of $-20 \mathrm{mV}$ from the holding potential. Series resistance values were typically between 4 and $12 \mathrm{M} \Omega$ and the membrane capacitance could be charged with a time constant between 100 and $400 \mu \mathrm{sec}$. Electronic compensation was used to reduce series resistance and membrane potential settling time to $40-70 \%$ of precompensation values.

When symptoms of poor space clamp could not be satisfactorily eliminated with series resistance compensation adjustments, the cell was excluded from quantitative analysis of currents. With sodium currents, 
inadequate space clamp was indicated by regenerative events during intermediate test steps and a steepening of the current-voltage relationship in the activation range. The measurement of $I_{\mathrm{A}}$ was more critically dependent on good space-clamp parameters than that of $I_{\mathrm{K}}$. Because activation kinetics are voltage dependent, the voltage gradient resulting from poor space clamp results in a delay of current activation, and this delay increases with distance from the pipet. Because $I_{\mathrm{A}}$ is only briefly activated before it inactivates, the effect of the delay is to reduce the magnitude of the peak current. In cases of poor space clamp, what appeared to be $I_{\mathrm{A}}$ on the basis of both rapid-activation kinetics and sensitivity to block by 4-aminopyridine (4-AP) was relatively insensitive to inactivation by depolarizing prepulses. To determine whether we were underestimating $I_{\mathrm{A}}$ in early motoneurons, we measured potassium currents in E4 and E6 motoneurons after only 4-6 hr in culture, when very little neurite outgrowth had occurred. Densities of $I_{\mathrm{A}}$ and $I_{\mathrm{K}}$ were similar to those measured after $1 \mathrm{~d}$ in culture.

Linear components of leak and capacitative current, though small, were eliminated from test-pulse traces by digital subtraction of the scaled control currents. Current density measurement data are expressed as mean \pm SEM. For quantitative measurements of $\mathrm{Na}^{+}$currents, $\mathrm{K}^{+}$ currents were reduced by including $5 \mathrm{~mm} \mathrm{4-AP}$ in the external saline and $70 \mathrm{~mm} \mathrm{Cs}^{+}$in the internal pipet solution. $\mathrm{K}^{+}$currents were measured with $\mathrm{KCl}$ in the internal pipet solution and $1 \mu \mathrm{M}$ TTX in the external solution to eliminate $I_{\mathrm{Na}}$.

For current-clamp recordings, a seal was first established in voltageclamp mode, and the membrane was ruptured in either voltage- or current-clamp mode. Very similar values of the resting membrane potential were obtained by the 2 procedures. Action potentials were evoked with 2 -msec-duration pulses of $100--900 \mathrm{pA}$. Action potential duration was measured as half repolarization time (HRT), defined as the time between the peak of the action potential and the point at which the membrane potential returned to the value halfway between the peak and starting potential. The more conventional measurement of action potential duration at half amplitude was not used because the stimulus artifact extended beyond that point in many of the low-amplitude action potentials of E4 neurons, in particular. Action potentials were compared at a varicty of holding potentials.

Effects of drugs were examined during continual perfusion of the small-volume recording chamber or by releasing small quantities from a hole in the tip of a U-shaped polyethylene tube, which was accomplished by closing off the vacuum at one end of the tube (McCobb et al., 1989). TTX, tetraethylammonium ion (TEA ${ }^{+}$), and 4-AP were dissolved in saline, and $\mathrm{pH}$ was adjusted as necessary. All experiments were conducted at room temperature $\left(\sim 20^{\circ} \mathrm{C}\right)$.

Solutions. Saline: $146 \mathrm{~mm} \mathrm{NaCl}, 5 \mathrm{~mm} \mathrm{KCl}, 2 \mathrm{~mm} \mathrm{CaCl}, 1 \mathrm{~mm}$ $\mathrm{MgCl}_{2}, 10 \mathrm{~mm}$ HEPES (pH, 7.4 with $\mathrm{NaOH}$ ); CMFS: $155 \mathrm{~mm} \mathrm{NaCl}$, $5 \mathrm{~mm} \mathrm{KCl,} 10$ mm HEPES (pH, 7.4 with $\mathrm{NaOH}$ ); MnP: 90\% Dulbecco's Modified Eagle's Medium (DMEM) (GIBCo, Grand Island, NY), 10\% horse serum with $100 \mathrm{U} / \mathrm{ml}$ penicillin and $100 \mu \mathrm{g} / \mathrm{ml}$ streptomycin; MnN: $85 \%$ DMEM with glutamine, $10 \%$ heat-inactivated horse serum: $5 \%$ chick cmbryo extract with $100 \mathrm{U} / \mathrm{ml}$ penicillin and $100 \mu \mathrm{g} / \mathrm{ml} \mathrm{strep}$ tomycin; external recording solutions: standard saline (as above) for current clamp, saline with $1 \mu \mathrm{M}$ TTX for $\mathrm{K}^{+}$currents, saline with $5 \mathrm{~mm}$ 4-AP for $\mathrm{Na}^{+}$currents; internal pipet solutions: $140 \mathrm{mM} \mathrm{KCl}, 5 \mathrm{~mm}$ $\mathrm{MgCl}_{2}, 10$ mм K $\mathrm{K}_{2}$ EGTA, $10 \mathrm{~mm}$ HEPES (pH, 7.4 with $\mathrm{KOH}$; used for both current clamp and $\mathrm{K}^{+}$current recordings); and $70 \mathrm{mM}$ Cs-aspartate, $70 \mathrm{~mm} \mathrm{KCl}, 5 \mathrm{~mm} \mathrm{MgCl}_{2}$, $5 \mathrm{~mm} \mathrm{Cs} \mathrm{EGTA}_{2}$, $5 \mathrm{~mm} \mathrm{~K}_{2}$ EGTA (pH, 7.4 with $\mathrm{CsOH}$; used for $\mathrm{Na}^{+}$current recordings).

\section{Results}

\section{Sodium currents in chick motoneurons}

Characterization. Figure 3 illustrates typical sodium currents recorded with a series of test-voltage steps $\left(V_{\text {test }}\right)$ from a holding potential $\left(\mathrm{V}_{\text {hold }}\right)$ of $-80 \mathrm{mV}$. $\mathrm{Na}^{+}$currents were found to be highly sensitive to block by TTX at all stages, including E4 (Fig. $3 C$ ). TTX at $100 \mathrm{~nm}$ virtually eliminated sodium currents ( $n=$ 9) and at $10 \mathrm{nM}$, reduced the sodium current by approximately $50 \%(n=3)$. The absence of a relatively TTX-resistant component in motoneurons is in contrast to dorsal root ganglion neurons (Bossu and Feltz, 1984) and myotubes (Weiss and Horn, 1986). No obvious developmental changes in voltage depen-
A

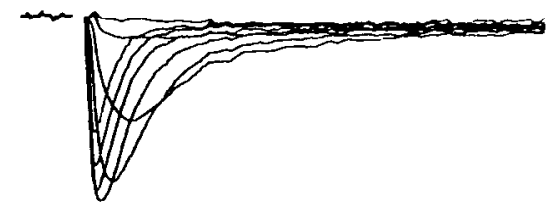

B

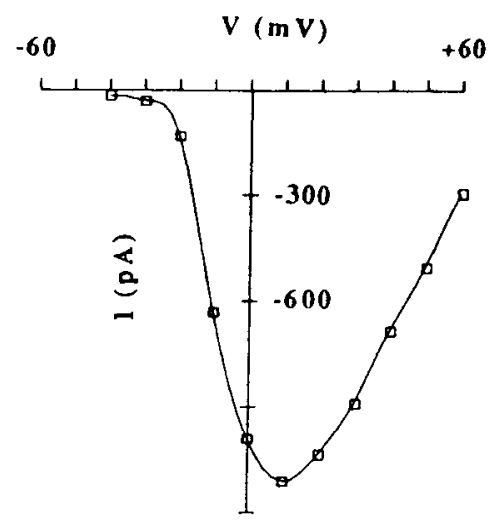

C

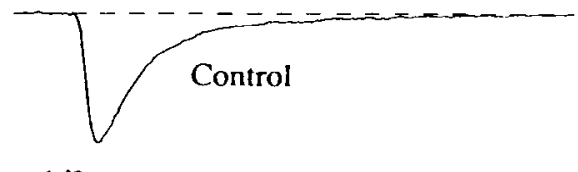

$\operatorname{TTX}(100 \mathrm{nM})$

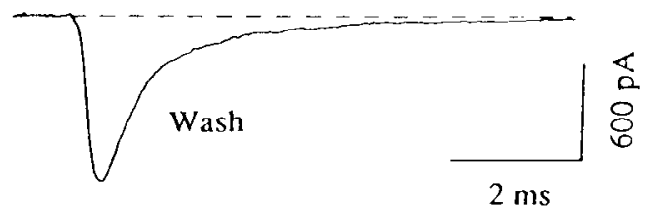

Figure 3. $\mathrm{Na}^{+}$currents measured with whole-cell voltage clamp in early chick limb motoncurons in vitro (E4, stages 22-24) identificd by retrograde labeling before dissociation. $A$, Currents evoked with a series of voltage steps (to between -30 and +40 , in $10-\mathrm{mV}$ increments) from a holding potential $\left(\mathrm{V}_{\text {hold }}\right)$ of $-80 \mathrm{mV} . B$, Peak current-voltage relationship for the currents displayed in $\mathrm{A}$. $C, \mathrm{Na}^{+}$currents measured in $\mathrm{E} 4$ and later motoneurons show consistently high sensitivity to block by TTX. Virtually complete block, as seen here, was achieved with 100 nм TTX.

dence or kinetics of activation or inactivation were observed. We saw no evidence for multiple components of $I_{\mathrm{Na}}$.

Developmental changes in expression of $\mathrm{Na}^{+}$currents. Quantitative comparisons of sodium current expression in motoneurons isolated from different staged embryos were made by measuring the maximum current amplitude elicited during a series of voltage steps from a holding potential of $-80 \mathrm{mV}$. Current amplitudes were normalized for cell size by dividing by cell capacitance, and are therefore expressed as current densities. Sodium current density in chick limb motoneurons was found to increase substantially during development. Motoneurons isolated from $\mathrm{E} 4$ chicks already expressed appreciable current (mean peak current density, $66.6 \pm 9.0 \mathrm{pA} / \mathrm{pF} ; n=21$ ); however, 
A

Figure 4. The development of $\mathrm{Na}^{+}$ current expression in chick limb motoncurons. $A$, Mcan values of $\mathrm{Na}^{+}$current density $( \pm$ SEM $)$ measured in motoneurons isolated from E4, E6, and E1 1 embryos $(n=21,21$, and 25 motoneurons, respectively). All recordings were made $1 \mathrm{~d}$ following isolation. Currents were normalized for cell size by dividing by membrane capacitance and are therefore expressed as $\mathrm{pA} / \mathrm{pF}$. Note that $I_{\mathrm{Na}}$ is already expressed at an appreciable level by E4 but shows a substantial further increase thereafter. $B$, Histograms of individual $\mathrm{Na}^{+}$current density values measured in E4, E6, and E11 motoneurons.
B

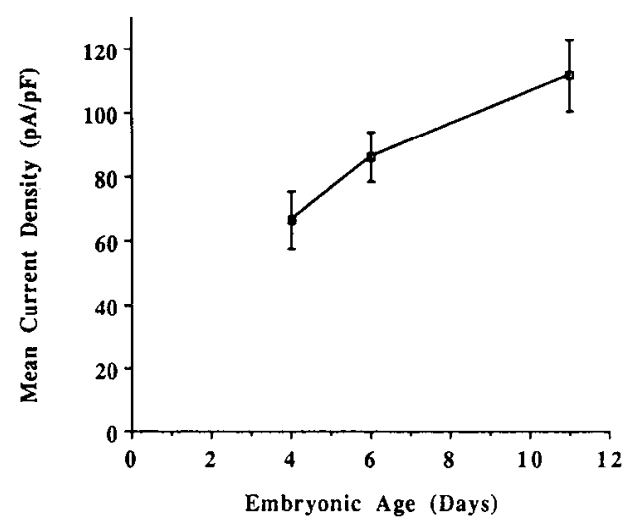

motoneurons isolated from E6 chicks expressed greater $I_{\mathrm{Na}}$ densities $(86.2 \pm 7.6 \mathrm{pA} / \mathrm{pF} ; n=21)$. A more moderate increase was seen between $\mathrm{E} 6$ and $\mathrm{E} 11$, with mean density reaching 112 $\pm 11.1 \mathrm{pA} / \mathrm{pF}(n=25$; Fig. 4$)$.

\section{Potassium currents}

Characterization. The voltage-dependent potassium currents observed in embryonic chick limb motoneurons could be resolved into 2 distinct components: a transient current similar to A-type potassium current in other cells $\left(I_{\mathrm{A}} ;\right.$ Rogawski, 1985), and a sustained current (referred to here as $I_{\mathrm{K}}$ ). Figure 5 illustrates potassium currents recorded from a motoneuron in response to a series of voltage steps from a holding potential of $-100 \mathrm{mV}$. Holding at more depolarized potentials briefly (prepulse duration, $100 \mathrm{msec}$ ) before stepping to the same test potentials was found to inactivate $I_{\mathrm{A}}$ selectively. The $I_{\mathrm{A}}$ component was found to activate much more rapidly than $I_{\mathrm{K}}$ (time to peak, $\sim 2-3 \mathrm{msec}$ for $I_{\mathrm{A}}$, compared to $\sim 10-20 \mathrm{msec}$ for $I_{\mathrm{K}}$ ) and to

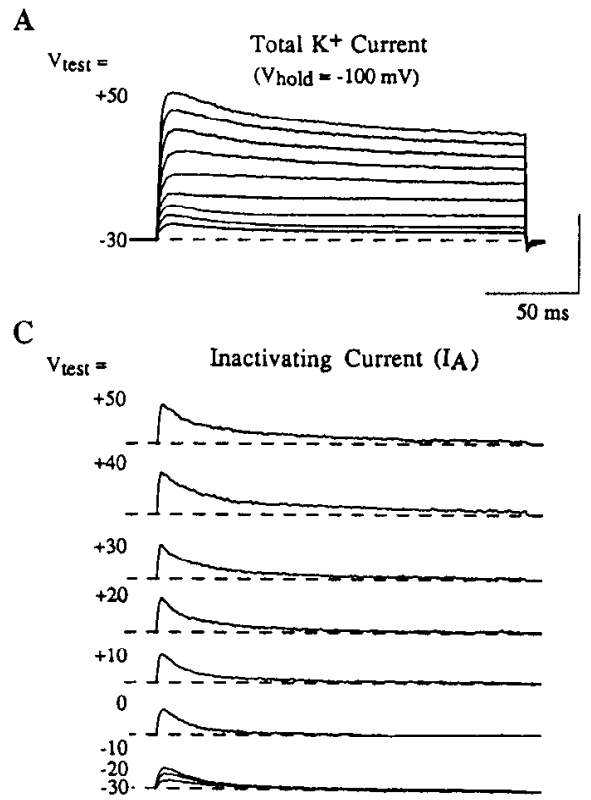

$\mathbf{B}$ $V_{\text {test }}=\quad$ Non-inactivating Current $\left(I_{K}\right)$
$\left(V_{\text {hold }}=-30\right.$ or $\left.-40 \mathrm{mV}\right)$

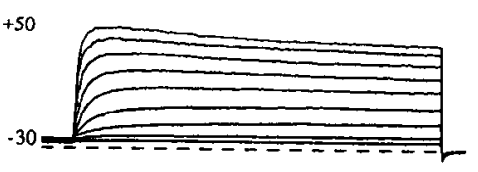

D

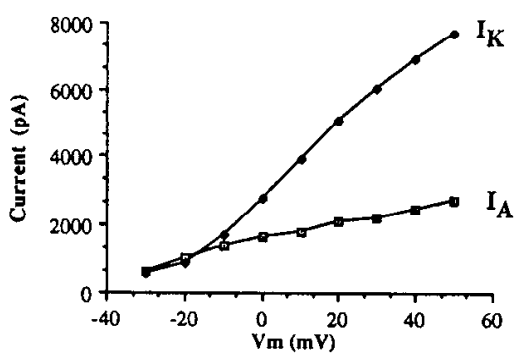

Figure 5. $\mathrm{K}^{+}$currents measured in an $\mathrm{E} 6$ chick limb motoneuron. $A$, Total $\mathrm{K}^{+}$current elicited by a series of steps to test potentials of -30 to +50 (in $10-\mathrm{mV}$ increments) applied from $\mathrm{V}_{\text {hold }}=-100 \mathrm{mV} . B, \mathrm{~K}^{+}$currents elicited when the same series of test potentials used in $A$ were preceded by a $100-\mathrm{msec}$ prepulse to $-30 \mathrm{mV}$ or $-40 \mathrm{mV}$. Note that this current, which is not inactivated by depolarizing prepulse potentials, decays little during the 200-msec-duration test step. Based on the similarity of its kinetics and voltage dependence to delayed-rectifier-type $\mathrm{K}^{+}$currents in other cells, it will be referred to here simply as $I_{\mathrm{K}}$. Prepulse potentials of $-30 \mathrm{mV}$ were used for test steps to -10 and above, and of $-40 \mathrm{mV}$ for steps to -30 and -20 . Prepulses to $-30 \mathrm{mV}$ activated a small amount of $\mathrm{K}^{+}$current, as indicated by the fact that the illustrated traces begin slightly above the zero-current baseline. Similar non-zero current "pedestals" are also evident in Figures 6 and 10 . $C$, Difference currents (records in $B$ subtracted from those in $A$ ) reveal the component of total $\mathrm{K}^{+}$current that is inactivated by the 100-msec prepulse described for $B$. This transient and readily inactivated $\mathrm{K}^{+}$current strongly resembles A-type potassium current in other cells and will be referred to here as $I_{\mathrm{A}} . D$, Peak currentvoltage relationship of $\mathrm{K}^{+}$current components shown in $B$ and $C$. 


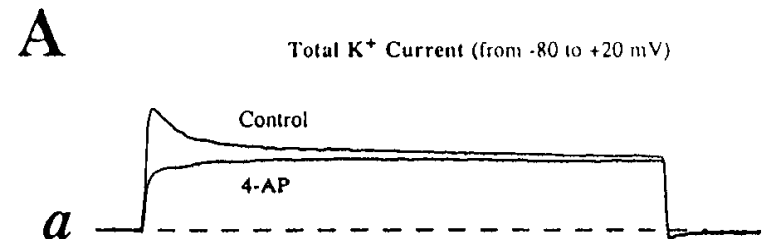

Noa-inactivating $\left(I_{K}\right)$ Current (from -40 to $+20 \mathrm{mV}$ )

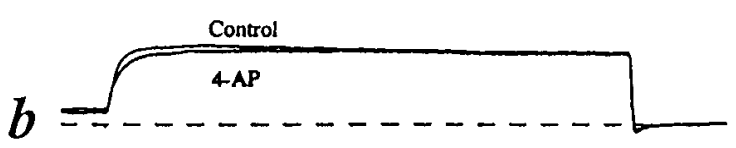

Inactivating $\left(\mathbf{I}_{\mathbf{A}}\right)$ Current

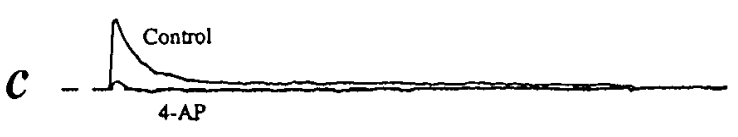

B

Total $K^{+}$Current (from-100 $10+20 \mathrm{mV}$ )

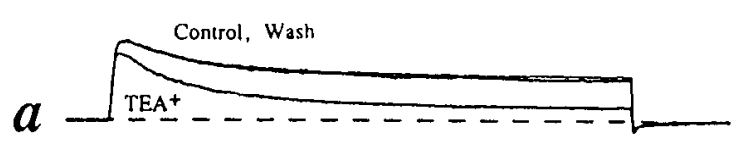

Non-inactivating $\left(\mathrm{I}_{\mathrm{K}}\right)$ Current (from -30 to $+20 \mathrm{mV}$ )
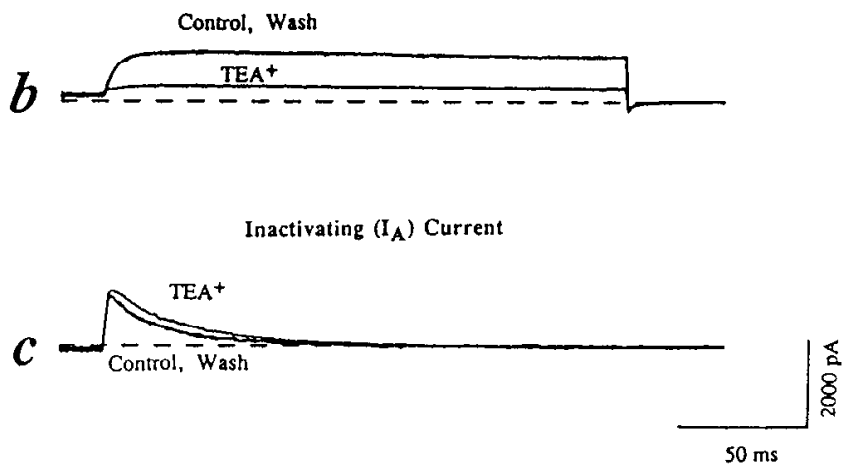

Figure 6. Inactivating $\left(I_{\mathrm{A}}\right)$ and noninactivating $\left(I_{\mathrm{K}}\right)$ components of the total $\mathrm{K}^{+}$current can be distinguished pharmacologically as well as by inactivation. $A, I_{\mathrm{A}}$ is selectively blocked by $4-\mathrm{AP}(5 \mathrm{~mm})$. $a$, Total $\mathrm{K}^{+}$current elicited by a step from $\mathrm{V}_{\text {hold }}=-100 \mathrm{mV}$ to $\mathrm{V}_{\text {test }}=+20 \mathrm{mV}$, before and in the presence of 4-AP. $b, 4$-AP has essentially no effect on $I_{\mathrm{K}}$, the noninactivating current elicited by a step to +20 that is preceded by a $100-\mathrm{msec}$ prepulse to $-40 \mathrm{mV} . c$, Difference currents $(a, b)$ showing the nearly complete block of $I_{\mathrm{A}}$ by $4-\mathrm{AP}$. $B, I_{\mathrm{K}}$ is selectively reduced by TEA ${ }^{+}$ $(25 \mathrm{~mm}) . a$, Total $\mathrm{K}^{+}$elicited by a step from $\mathrm{V}_{\text {hotd }}=-100$ to $\mathrm{V}_{\text {test }}=+20 \mathrm{mV}$ before, during, and after exposure to TEA ${ }^{+} . b$, TEA ${ }^{+}$causes a large reduction in $I_{\mathrm{K}}$, elicited when the test step to $+20 \mathrm{mV}$ is preceded by a $100-\mathrm{msec}$ prepulse to $-30 \mathrm{mV}$. Note that this noninactivating current is reduced by approximately the same amount as the component of the total current, which is sustained until the end of the test pulse in $a$. $c$, The difference currents $(a, b)$ demonstrate that the inactivating component $\left(I_{\mathrm{A}}\right)$ is not reduced by TEA ${ }^{+}$. The small apparent enhancement of $I_{\mathrm{A}}$ by $\mathrm{TEA}^{+}$probably reflects the improved space-clamp conditions resulting from the block of $I_{\mathrm{K}}$.

exhibit rapid decay during a sustained test potential. The time constant of $I_{\mathrm{A}}$ decay during a step to $+20 \mathrm{mV}$ was typically $\sim 30 \mathrm{msec}$. Partial inactivation of the current could be observed in some cases at holding potentials as negative as $-90 \mathrm{mV}$. The current was typically half-inactivated at -60 or $-50 \mathrm{mV}$ and could be completely inactivated by $100-\mathrm{msec}$ prepulse potentials to -40 or $-30 \mathrm{mV}$. The inactivating component could be eliminated by exposure to 4-AP (concentration, $5 \mathrm{~mm}$ ) with no reduction of the noninactivating current component. This further substantiates the identification of the inactivating component as $I_{\mathrm{A}}$ (Fig. 6). $I_{\mathrm{A}}$ was not reduced by extracellular TEA ${ }^{+}$ even at the high concentration of $25 \mathrm{~mm}$.

The current referred to as $I_{\mathrm{K}}$ was not inactivated by brief depolarizing prepulses that eliminated $I_{\mathrm{A}}$, decayed with a much slower time constant during sustained steps (typically 12-14 sec at $+20 \mathrm{mV}$ ), and was not reduced in magnitude by 5 mм 4-AP (Fig. 6). $I_{\mathrm{K}}$ was substantially $(\sim 80-90 \%)$ but not fully blocked by $25 \mathrm{mM} \mathrm{TEA}^{+}$.

Because EGTA (10 mM) was included in the internal solution, it seems unlikely that $\mathrm{Ca}^{2+}$-activated $\mathrm{K}^{+}$currents $\left(I_{\mathrm{K}(\mathrm{Ca})}\right)$ would have contributed to the $\mathrm{K}^{+}$current we measured. Indeed, neither $I_{\mathrm{K}}$ nor $I_{\mathrm{A}}$ exhibited features of $I_{\mathrm{K}(\mathrm{Ca})}$, such as $N$-shaped dependence of peak current on test potential. Very similar currents were also recorded with $10 \mathrm{~mm}$ BAPTA internally. Neither reducing nor elcvating external $\mathrm{Ca}^{2+}$ concentrations (to 0 and 10 $\mathrm{mM}$, respectively) had any effect on the $\mathrm{K}^{+}$currents recorded from single cells (with the possible exception of small shifts in voltage dependence).

Developmental changes in expression of $K^{+}$currents. Both $I_{\mathrm{A}}$ and $I_{\mathrm{K}}$ were present in at least some chick limb motoneurons at all stages of development studied (Fig. 7), and no changes in kinetic, voltage dependence, or pharmacological properties were observed during development. However, a large change in density of $I_{\mathrm{A}}$ did occur during development, while a relatively small change was seen in density of $I_{\mathrm{K}}$. Quantitative comparisons of $I_{\mathrm{A}}$ and $I_{\mathrm{K}}$ expression in motoneurons isolated from different stage embryos were made according to the following criteria: potassium currents were elicited by stepping for $200 \mathrm{msec}$ to a test potential of $+20 \mathrm{mV}\left(\mathrm{V}_{\text {test }}\right)$, first from a holding potential of $-100 \mathrm{mV}$, and then from a prepulse potential of $-30 \mathrm{mV}$ (duration $100 \mathrm{msec}$ ); $I_{\mathrm{K}}$ was measured as the current sustained until the end of the $+20-\mathrm{mV}$ test step that was preceded by the $-30-\mathrm{mV}$ prepulse; $I_{\mathrm{A}}$ was measured as the peak of the difference current obtained by digital subtraction of the 2 test currents and thus represents the current component inactivated by the prepulse at $-30 \mathrm{mV}$.

At E4, potassium current was almost exclusively comprised of $I_{\mathrm{K}}$, with $I_{\mathrm{A}}$ either small or absent. Therefore, 16 of 17 neurons expressed an $I_{\mathrm{A}}$ density of less than $10 \mathrm{pA} / \mathrm{pF}$. By contrast, in E11 motoneurons, the smallest observed density of $I_{\mathrm{A}}$ was 23 $\mathrm{pA} / \mathrm{pF}$, and the largest was $143 \mathrm{pA} / \mathrm{pF} . I_{\mathrm{A}}$ densities measured in $\mathrm{E} 6$ motoneurons were consistently intermediate between those measured in E4 and E11 motoneurons (Fig. 7B).

As illustrated in Figure 7 A, an increase of approximately 16 fold was observed in mean density of motoneuron $I_{\mathrm{A}}$ between E4 and E11. Peak current densities at E4, E6, and E1 1 were 3.9 $\pm 1.4,26.8 \pm 3.5$, and $65.5 \pm 8.6 \mathrm{pA} / \mathrm{pF}(n=17$ at each age $)$ During the same developmental span, $I_{\mathrm{K}}$ increased by only ap- 
A

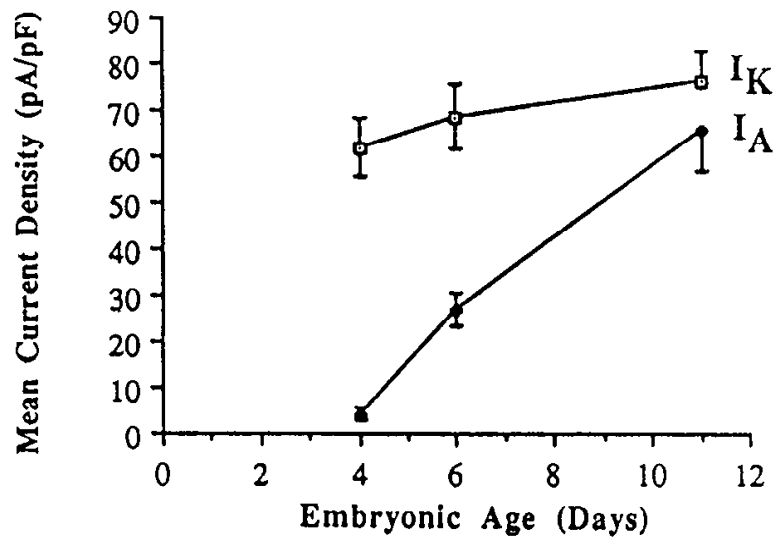

B

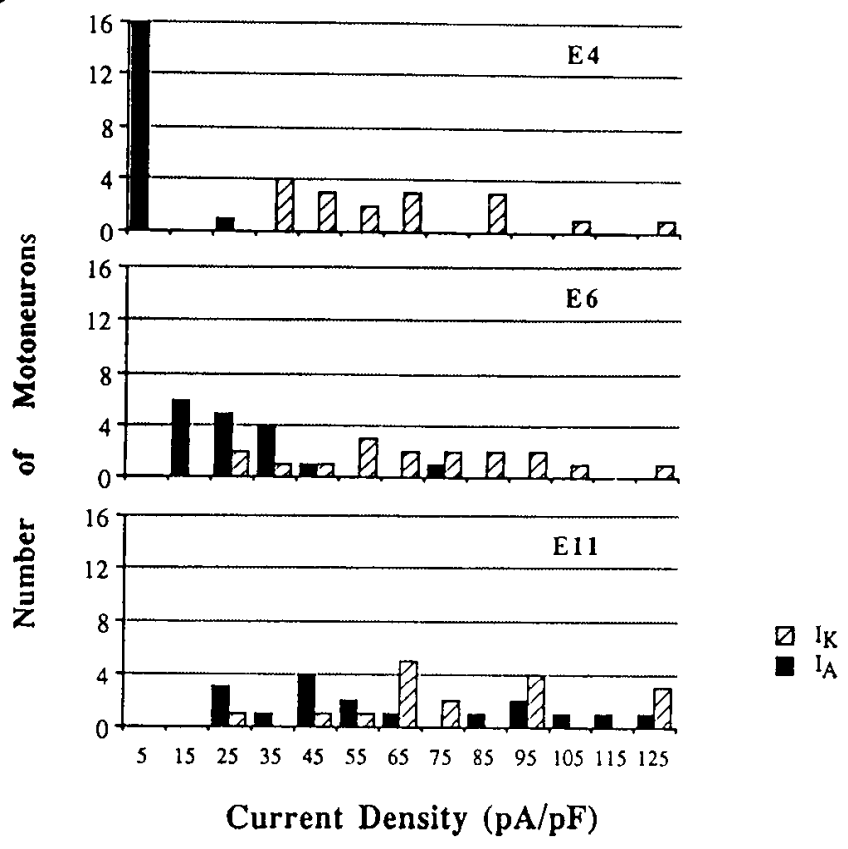

Figure 7. Development of $\mathrm{K}^{+}$currents in chick limb motoneurons. $A$, Mean values $( \pm \mathrm{SEM})$ of current densities $(\mathrm{pA} / \mathrm{pF})$ measured in motoneurons isolated at E4, E6, or E11 ( $n=17$ motoneurons for each stage). Currents were measured after $1 \mathrm{~d}$ in culture. Note that the expression of $I_{\mathrm{K}}$ is already appreciable at $\mathrm{E} 4$ and that the density of this current increases by only approximately $25 \%$ during the period from E4 to E1 1 . By contrast, $I_{\mathrm{A}}$ is small or absent at E4 and increases in mean density by more than 16 -fold by E11. Currents were recorded for 200 -msec test pulses to +20 $\mathrm{mV}\left(\mathrm{V}_{\text {hold }}=-100 \mathrm{mV}\right)$ with and without a 100 -msec duration prepulse to $-30 \mathrm{mV}$. $I_{\mathrm{A}}$ was measured as the peak of the difference between currents with and without the prepulse, and $I_{\mathrm{K}}$ was measured as the current sustained until the end of the test pulse that was preceded by a prepulse. $B$, Histogram of $I_{\mathrm{A}}$ (solid bars) and $I_{\mathrm{K}}$ (hatched bars) densities measured in motoneurons from E4, E6, and E11 chick embryos. The distribution of $I_{\mathrm{K}}$ densities changed little during development, while $I_{\mathrm{A}}$ density values increased substantially between E4 and E6 and again between E6 and E1 1 .

proximately $25 \%$. Mean densities of $I_{\mathrm{K}}$ were $61.9 \pm 6.3,68.6$ \pm 6.9 , and $76.2 \pm 6.8 \mathrm{pA} / \mathrm{pF}$, respectively ( $n=17$ at each stage).

\section{Action potential maturation in chick limb motoneurons}

Nearly all healthy motoneurons isolated from E4 and later-stage embryonic chicks were capable of generating overshooting action potentials in response to depolarizing pulses during current clamp recording. Action potential amplitudes increased with development between E4 and E11. Action potentials of E4 motoneurons peaked at between $-2 \mathrm{mV}$ and $+30 \mathrm{mV}$ (mean, 15.7 $\pm 3 \mathrm{mV} ; n=12$ ), whereas action potentials of $\mathrm{E} 11$ motoneurons peaked between +16 and $+49 \mathrm{mV}$ (mean, $27.3 \pm 5 \mathrm{mV} ; n=$ 7). Action potential repolarization was typically much more rapid in E11 motoneurons than in earlier motoneurons. The time required for repolarization to a value halfway between the peak voltage and the voltage from which action potentials were evoked (between -81 and $-85 \mathrm{mV}$ ) was measured (HRT; Fig. 8). HRT ranged from 1.6 to $8.4 \mathrm{msec}$ for $\mathrm{E} 4$ motoneurons and from 1.0 to $1.8 \mathrm{~ms}$ for E11 motoneurons. Mean HRTs were 3.7 $\pm 0.6,2.0 \pm 0.2$, and $1.5 \pm 0.1 \mathrm{msec}$ for E4, E6, and E1 1 motoneurons, respectively ( $n=12,13$, and 12 motoneurons). The same developmental decrease in HRT was observed for action potentials evoked from -61 to $-65 \mathrm{mV}$; however, the difference was smaller, presumably because these more depolarized potentials caused partial inactivation of $I_{\mathrm{A}}$, a current that plays an important role in action potential repolarization (Fig. 9).

Pharmacological agents were used to determine which ionic currents control the form of the action potential. Motoneurons were inexcitable in TTX $(1 \mu \mathrm{M})$, indicating that regenerative excitation is attributable to sodium current, with minimal contribution of calcium current. This is consistent with the relatively small size of calcium currents measured in these neurons (McCobb et al., 1989). Action potential duration was controlled by both potassium currents. Under conditions in which both $I_{\mathrm{A}}$ and $I_{\mathrm{K}}$ would be active, $I_{\mathrm{A}}$ played the dominant rolc in repolarization. This is illustrated in Figure 9: the addition of 4-AP alone caused significant prolongation of the action potential (Fig. $9 A$, upper panel), whereas the addition of $\mathrm{TEA}^{+}$alone did not (Fig. 9A, lower panel). However, when $I_{\mathrm{A}}$ is not present (because it is blocked by 4-AP), the addition of TEA ${ }^{+}$does cause broadening of the action potential (Fig. $9 B$ ).

The voltage dependence of $I_{\mathrm{A}}$ inactivation may play an important role in regulation of the duration of motoneuron action potentials. Action potentials elicited from a negative holding potential were much briefer than those elicited from a more positive potential (Fig. 9C). That the difference results from inactivation of $I_{\mathrm{A}}$ is supported by the similarity of the effect of 4-AP on action potential duration: as seen in Figure 9C, 4-AP ( $3 \mathrm{mM}$ ) prolonged the action potential elicited from $-85 \mathrm{mV}$ to about the same degree as did changing the holding potential to $-54 \mathrm{mV}$. In voltage clamp experiments, $I_{\mathrm{A}}$ was found to bc virtually eliminated by holding at $-50 \mathrm{mV}$. This is consistent with the idea that voltage-dependent inactivation of $I_{\wedge}$ is largely responsible for the voltage dependence of action potential duration.

Figure 10 summarizes the above-described developmental changes in motoneuron action potentials, potassium currents, 
and sodium currents by presenting representative recordings from motoneurons at the 3 embryonic ages studied. Action potential amplitude and duration show progressive increases and decreases, respectively, with development. The increase in the transient component $\left(I_{\mathrm{A}}\right)$ of the potassium current parallels the decrease in action potential duration, and the increase in $I_{\mathrm{Na}}$ parallels the increase in action potential amplitude. Note that only a small part of the increase in absolute current magnitudes, as shown here, can be explained by the developmental increasc in motoncuron size (see Materials and Methods), while the larger part results from increases in current densities.

\section{Discussion}

Current- and voltage-clamp techniques were used to characterize the state of electrophysiological differentiation of chick limb motoneurons beginning at the earliest time that they can be positively identified and to chart changes occurring as the limb neuromuscular system proceeds through the early, and most important, phase of its differentiation. Three major currents appear to dominate the action potential mechanism of these neurons: a highly TTX-sensitive sodium current $\left(I_{\mathrm{Na}}\right)$, a relatively sustained, delayed-rectifier-type potassium current $\left(I_{\mathrm{K}}\right)$, and a more rapidly-activating, transient potassium current $\left(I_{\mathrm{A}}\right)$. Comparisons of current densities between motoneurons from embryos of different stages revealed large developmental changes. Consistent with the early appearance of TTX-sensitive action potentials, appreciable $I_{\mathrm{Na}}$ expression was observed in motoneurons isolated as early as E4. Substantial increase occurred thereafter as well, with a consequent increase in action potential amplitude. $I_{\mathrm{K}}$ expression was also already high at $\mathrm{E} 4$ but showed a more moderate increase thereafter, compared with $I_{\mathrm{Na}}$. The development of $I_{\mathrm{A}}$ expression markedly differed from that of $I_{\mathrm{Na}}$ and $I_{\mathrm{K}} . I_{\mathrm{A}}$ was small at E4 and increased 16-fold by E11. The developmental decline in the duration of the repolarization phase of the action potential can be explained by this increase in $I_{\mathrm{A}}$. Interestingly, the expression of the 3 current types develops on different schedules, further supporting the idca that expression of individual currents can be under differential regulatory control (McCobb et al., 1989).

The sequence of development of ionic currents in chick limb motoneurons, in which $\mathrm{Ca}^{2+}$ current maturation (McCobb et al., 1989) lags behind $I_{\mathrm{Na}}$ and $I_{\mathrm{K}}$, appears more similar to that reported for avian neural crest cells (Bader et al., 1983, 1985), rat sympathetic neurons (Nerbonne et al., 1986; Nerbonne and Gurney, 1989), and mouse spinal neurons (Krieger and Sears, 1988) than to that reported in amphibian spinal neurons (Barish, 1986; O'Dowd et al., 1988). In the latter neurons, the early development of $I_{\mathrm{Ca}^{2}+}$ relative to $I_{\mathrm{Na}}$ and $I_{\mathrm{K}}$ enables the generation of very long duration $(\sim 100 \mathrm{msec}) \mathrm{Ca}^{2+}$-dependent action potentials before much briefer $\mathrm{Na}^{+}$-dependent action potentials (Baccaglini and Spitzer, 1977; Spitzer, 1985; Barish et al., 1986; O'Dowd et al., 1988). In the context of neuromuscular development, such $\mathrm{Ca}^{2+}$ action potentials could play an important regulatory role if they were to occur. In chick limb motoneurons, however, the very early development of $I_{\mathrm{K}}$ expression would tend to preclude long-duration action potentials. Furthermore, $\mathrm{N}$ - and L-type $\mathrm{Ca}^{2+}$ current density is very small at E4, the earliest stage studied (McCobb et al., 1989). At E4, T-type $\mathrm{Ca}^{2+}$ current density is larger than that of $\mathrm{N}$ - and L-types, but still small compared to $I_{\mathrm{Na}}$. The subsequent developmental decrease in $\mathrm{T}$-current density implies that any regenerative events de-
A

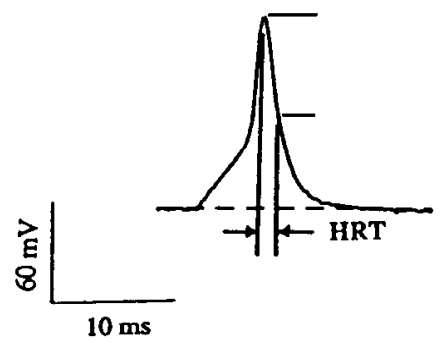

B

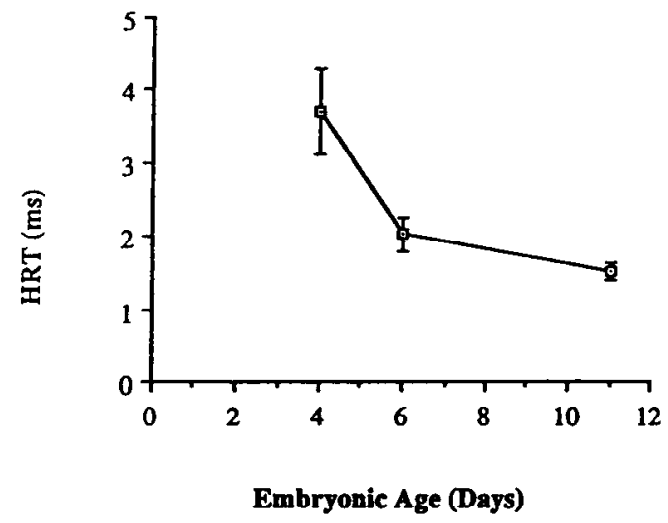

Figure 8. Developmental change in action potential duration. $A$, HRT is defined as the time between the peak of the action potential and the time at which the membrane potential has returned to the level halfway between the peak and the potential prior to the action potential stimulus. $B$. Mean ( \pm SEM) HRT values for action potentials elicited from $E 4$, E6, and E11 motoneurons ( $n=12,13$, and 12, respectively). For each neuron, several action potentials were evoked from holding potentials ranging from -81 to $-85 \mathrm{mV}$, and HRT values were averaged. See Figure 10 for representative action potential waveforms at the different stages.

pendent on this current would have to occur very early in motoneuron maturation.

$I_{\mathrm{A}}$ activates more rapidly than $I_{\mathrm{K}}$ and thus brings about more rapid action potential repolarization. Therefore, while early development of $I_{\mathrm{K}}$ prevents very long duration action potentials, action potential duration still declines substantially with the development of $I_{\mathrm{A}}$. Furthermore, the voltage-dependent inactivation of $I_{\mathrm{A}}$ provides more mature motoneurons with a mechanism for adjusting action potential duration as a function of membrane potential. The relatively late appearance of $I_{\mathrm{A}}$ and its effects on the action potential have also been reported in rat sympathctic ncurons (Nerbonne et al., 1986) and unidentified spinal neurons of the mouse and Xenopus (Krieger and Sears, 1988; Ribera and Spitzer, 1990). Interestingly, in Drosophila. flight muscle $I_{\mathrm{A}}$ develops before the delayed rectifier current rather than after it (Salkoff and Wyman, 1981).

The developmental changes in whole-cell current density reported here are most easily explained by changes in ion channel numbers rather than modification of single channel properties (e.g., conductance, open probability, ion selectivity). While measured single channel properties change with neuronal development (Blair and Dionne, 1985; Harris et al., 1988; Yool et al., 1988), it is not clear whether such changes result from expression of new channels or modification of properties of channels already expressed. In the present studies, the consistency, over 
A
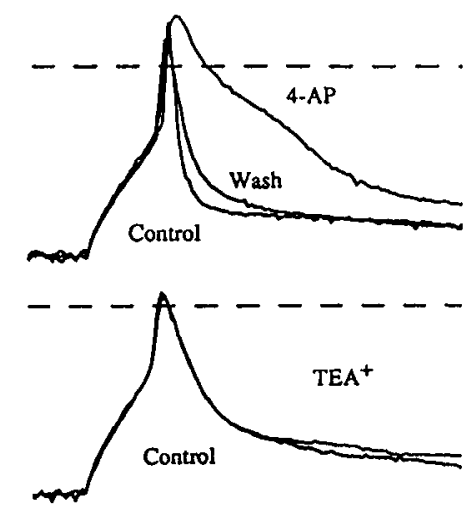

B

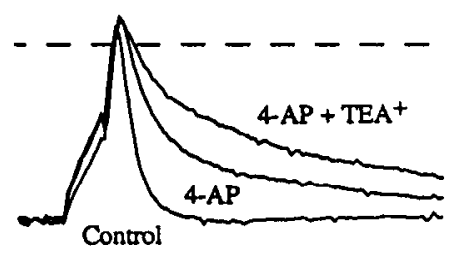

C
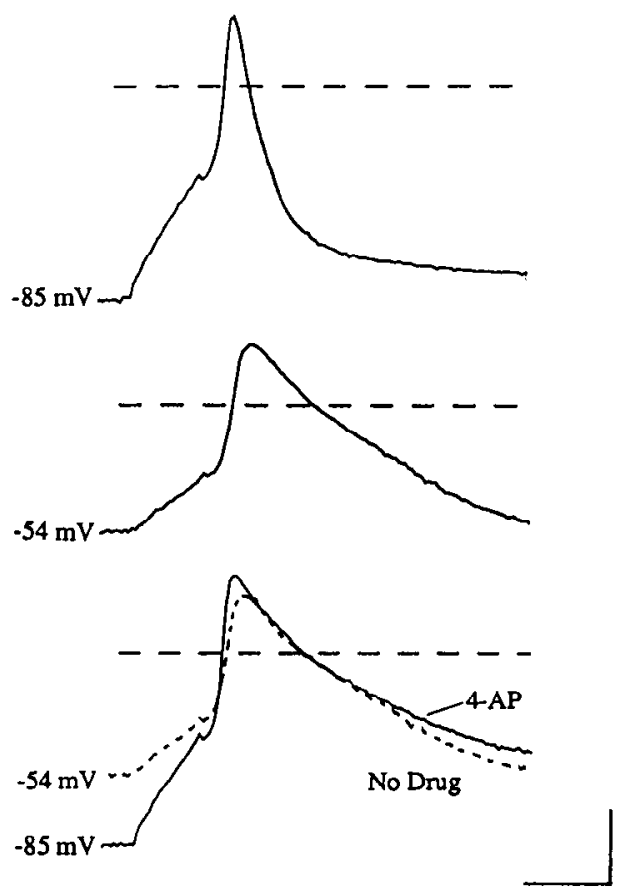

Figure 9. Contributions of 4-AP-sensitive $\left(I_{\mathrm{A}}\right)$ and TEA ${ }^{+}$-sensitive $\left(I_{\mathrm{K}}\right)$ currents to action potential repolarization in motoneurons. $A$, Action potentials in an E6 motoneuron were evoked from a holding potential of $-80 \mathrm{mV}$ before, during, and after exposure to $5 \mathrm{~mm} 4$-AP ( $t o p$ set of traces) and $25 \mathrm{mM} \mathrm{TEA}^{+}$(bottom set of traces). TEA ${ }^{+}$alone had little effect on action potential repolarization, whereas 4-AP alone prolonged the action potential considerably. $B$, Although TEA ${ }^{+}$alone has little effect on action potential repolarization, TEA $\mathrm{T}^{+}\left(25 \mathrm{~mm}^{-}\right.$does cause a substantial prolongation when it is added after $I_{\mathrm{A}}$ has been blocked by 4-AP. C, Depolarized holding potentials produced action potential broadening comparable to that produced by 4-AP. In the absence of 4-AP, an action potential elicited from a holding potential of $-54 \mathrm{mV}$ (center panel) is broadened relative to the action potential elicited from $-85 \mathrm{mV}$ (top panel). The bottom panel compares the action potential elicited from - $54 \mathrm{mV}$ in the absence of drug (replotted as the dashed trace) with an action potential elicited from $-85 \mathrm{mV}$ in the presence of $3 \mathrm{~mm} 4$-AP (solid trace). The similarity of the repolarization phase of the 2 traces suggests that depolarization-induced broadening of the action potentials results from inactivation of $I_{\mathrm{A}}$. Calibration bars: horizontal, $10 \mathrm{msec}$; vertical, $30 \mathrm{mV}$.

development, of voltage dependence, kinetic, and pharmacological features of the 3 current components suggests that changes in channel expression outwcigh modification of chasincl properties and are sufficient to explain the observed changes in the action potential.

While longitudinal studies of individual developing neurons would be ideal, we believe that the population studies reported here present a valid picture of the general progression of motoneuron development. Between E4 and E6, the population is relatively stable, because only a small percentage of motoneurons are born after E4 (Hamburger, 1977). After E6 and before E11, approximately $50 \%$ of the population succumbs to cell death (Hamburger, 1975, 1977). Although we cannot exclude the possibility that cells fated to die in vivo may not have survived to be sampled in vitro, it seems likely that the data for $\mathrm{E} 4$, at least, and probably E6, as well, represent motoneurons of both fates. We have not yet been able to resolve a bimodal distribution of any electrophysiological feature that might predict the fate of individual cells.

Ideally, the quantitative measurements reported here would have been made immediately after spinal cord dissociation to avoid the complication of possible changes in ionic currents in culture. However, acutely isolated neurons were too delicate to record from reproducibly, and recordings were made more easily and consistently when the neurons were given a day to recover from the trauma of dissociation. Voltage- and current-clamp recordings made on acutely dissociated motoneurons did give results qualitatively similar to those obtained a day later. Motoneurons acutely isolated from E4 embryos exhibited $I_{\mathrm{Na}}$ and action potentials (as well aso $I_{K}$ ), suppowting the visy carly disferentiation of excitability per se. Cells allowed to remain in culture longer than $1 \mathrm{~d}$ after dissociation grew neurites extensive enough to interfere with the attainment of good voltage control (space clamp). Therefore, we do not yet know whether expression of currents changes quantitatively with time in vitro.

Necessarily, the procedures for spinal cord dissociation differed between embryonic stages (see Materials and Methods). Could the differences contribute to differences in measured current densities? We were consistent for each developmental stage in sampling the healthiest motoneurons in each of a minimum of 5 separate, and by visual inspection comparably healthy, experimental cultures. The trends of developmental increases in $I_{\mathrm{Na}}$ and $I_{\mathrm{A}}$ densities were pronounced and were seen in both the absolute range of values observed and the mean values. Furthermore, the different schedule of changes in $I_{\mathrm{Na}}, I_{\mathrm{A}}$, and $I_{\mathrm{K}}$ make it very unlikely that the developmental patterns result from treatment differences. $\mathrm{Ca}^{2+}$ currents measured in motoneurons from the same stages showed a pattern even less likely to arise from treatment differences, with developmental increases in $\mathrm{N}$ - and L-type $\mathrm{Ca}^{2+}$ currents coinciding with a large decrease in T-type current (McCobb et al., 1989)

How might changes in intrinsic excitability of motoneurons affect neuromuscular system development? Excitability and action potential waveform are very important determinants of 
E4

Action Potentials
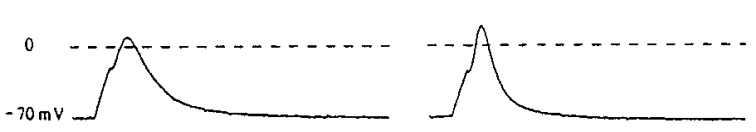

$\mathrm{K}^{+}$Currents

Total
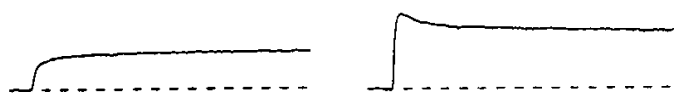

IK
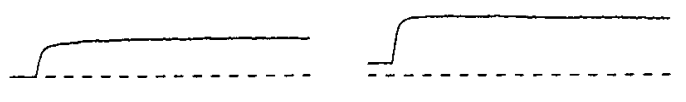

$I_{A}$
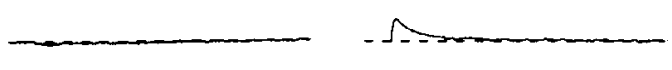

$\mathrm{Na}^{+}$Currents
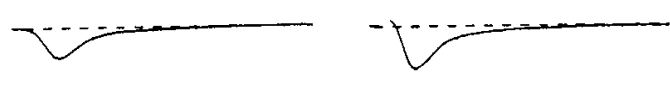

E11
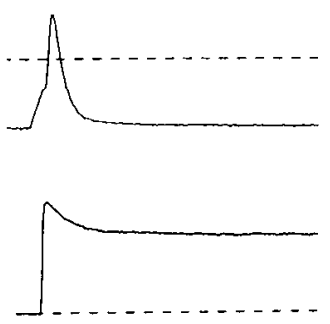

Figure 10. Summary of changes in electrophysiological properties of chick hindlimb motoneurons. Representative examples of action potentials and ionic currents recorded from motoneurons isolated at embryonic ages are indicated. Note the progressive increase in action potential amplitude and decrease in duration. Action potentials were elicited from a holding potential of $-70 \mathrm{mV}$. Potassium currents show a large proportionate increase in the rapidly activating transient component, identifiable as $I_{\mathrm{A}}$. Sodium current amplitude increases progressively with development. Horizontal calibration bar: $10 \mathrm{msec}, 75 \mathrm{msec}$, and $2 \mathrm{msec}$ for action potentials, potassium currents, and sodium currents, respectively. Vertical calibration bar: $52 \mathrm{mV}$ for action potentials, $2 \mathrm{nA}$ for all currents.
$\mathrm{Ca}^{2+}$ entry through voltage-gated channcls. These features are changing substantially even as $\mathrm{Ca}^{2+}$ currents themselves are differentiating (McCobb et al., 1989). This adds support to the suggestion already put forth that changes in voltage-dependent $\mathrm{Ca}^{2+}$ entry in motoneurons might control neuromuscular differentiation (McCobb and Beam, 1990). Motoneuronal cell death, for example, could be affected by $\mathrm{Ca}^{2+}$ entry as a result of either indirect or direct mechanisms. An indirect mechanism is suggested because voltage-dependent $\mathrm{Ca}^{2+}$ entry controls trans-synaptic activation of muscle contraction, which in turn influences 'motoneuron survival during the per lod of horinal cell death in vivo. Specifically, blocking activity increases survival (Laing and Prestige, 1978; Pittman and Oppenheim, 1978, 1979), while increasing activity decreases survival (Oppenheim and Núñez, 1982). This raises the possibility that the timing of differentiation of excitability in motoneurons triggers cell death by enabling the onset of neuromuscular transmission. Directly, increasing $\mathrm{Ca}^{2+}$ entry might either make cells more vulnerable to death (Choi, 1987) or protect against death (as does entry through L-type channels in several neuronal types in vitro; Collins and Lile, 1989; Koike et al., 1989). It is interesting to speculate that the development of $I_{\mathrm{A}}$ (and rapid repolarization) might play a role that counterbalances the effect of increasing excitability. Thus, by limiting $\mathrm{Ca}^{2+}$ entry during the action potential, this current might decide the fate of individual motoneurons with respect to cell death.

\section{References}

Baccaglini PI, Spitzer NC (1977) Developmental changes in the inward current of the action potential of Rohan-Beard neurones. I Physiol 271:93-117.

Bader CR, Bertrand D, Dupin E, Kato AC (1983) Development of electrical mcmbrane properties in cultured avian neural crest. Nature 305:808-810.

Bader CR, Bertrand D, Dupin E (1985) Voltage-dependent potassium currents in developing neurones from quail mesencephalic neural crest. J Physiol 366:129-151.

Barish ME (1986) Differentiation of voltage-gated potassium current and modulation of excilability in cultured amphibian spinal neurones. J Physiol 375:229-250.

Barrett EF, Barrett JN, Crill WE (1980) Voltage-sensitive outward currents in cat motoneurones. J Physiol 304:251-276.

Betz WJ (1987) Motoneuron death and synapse elimination in vertebrates. In: The vertebrate neuromuscular junction, pp 117-162. New York: Alan R. Liss.

Blair LAC, Dionne VE (1985) Developmental acquisition of $\mathrm{Ca}^{2+}$ sensitivity by $\mathrm{K}^{+}$channels in spinal neurones. Nature 315:329-331.

Eossu J-1, Faltz A (1984) Patch ciamp study of the tetrodotoxinresistant sodium currents in group $\mathrm{C}$ sensory neurones. Neurosci Lett 51:241-246.

Brown MC (1984) Sprouting of motor nerves in adult muscles: a recapitulation of ontogeny. Trends in Neurosci 11:10-14.

Choi DW (1987) Ionic dependence of glutamate neurotoxicity. J Neurosci 7:369-379.

Collins F, Lile JD (1989) The role of dihydropyridine-sensitive voltage-gated calcium channels in potassium-mediated neuronal survival. Brain Res 502:99-108.

Dahm LM, Landmesser LT (1988) The regulation of intramuscular nerve branching during normal development and following activity blockade. Devel Biol 130:621-644.

Dennis MJ (1981) Development of the neuromuscular junction: inductive interactions between cells. Ann Rev Neurosci 4:43-68.

Ding R, Jansen JKS, Laing NG, Tønnesen H (1983) The innervation of skeletal muscles in chickens curarized during early development. J Neurocytol 12:887-919.

Fruns M, Krieger C, Sears TA (1987) Identification and electrophysiological investigations of embryonic mammalian motoneurons in culture. Neurosci Lett 83:82-88.

Fulton BP, Walton K (1986) Electrophysiological properties of neonatal rat motoneurons studied in vitro. J Physiol 370:651-678.

Hamburger V (1975) Cell death in the development of the lateral motor column of the chick embryo. J Comp Neurol 160:535-546.

Hamburger V (1977) The developmental history of the motor neuron. Neurosci Res Program Bull 15 (Suppl. 111):1-37.

Hamburger V, Hamilton HL (1951) A series of normal stages in the development of the chick embryo. J Morph 88:49-92.

Hamill OP, Marty A, Neher E, Sakmann B, Sigworth FJ (1981) Im- 
proved patch-clamp techniques for high-resolution current recording from cells and cell-free membrane patches. Pfluegers Arch 391:85100.

Harris GL, Henderson LP, Spitzer NC (1988) Changes in densities and kinetics of delayed rectifier potassium channels during neuronal differentiation. Neuron 1:739-750.

Honig MG, Humc RI (1986) Fluorescent carbocyanine dyes allow living neurons of identified origin to be studied in long term cultures. J Cell Biol 103:171-187.

Jacobson M (1978) Developmental neurobiology. New York: Plenum.

Koike T, Martin DP, Johnson EM Jr (1989) Role of $\mathrm{Ca}^{2+}$ channels in the ability of membrane depolarization to prevent neuronal death induced by trophic-factor deprivation: evidence that levels of internal $\mathrm{Ca}^{2+}$ determine nerve growth factor dependence of sympathetic ganglion cells. Proc Natl Acad Sci USA 86:6421-6425.

Krieger C, Sears TA (1988) The development of voltage-dependent ionic conductances in murine spinal cord neurones in culture. Can J Physiol Pharmacol 66:1328-1336.

Laing NG (1982) Timing of motoneuron death in brachial and lumbar regions of the chick embryo. Devel Brain Res 5:181-186.

Laing NG, Prestige MC (1978) Prevention of spontancous motoneurone death in chick embryos. J Physiol 282:33P-34P.

Mallart A (1984) Presynaptic currents in frog motor endings. Pfluegers Archiv 400:8-13.

McCobb DP, Beam KG (1990) Voltage-dependent $\mathrm{Ca}^{2+}$ entry and neuromuscular system development. FIDIA Res Found Symp Ser 4: in press.

McCobb DP, Best PM, Beam KG (1989) Development alters the expression of calcium current in chick limb motoneurons. Neuron 2: 1633-1643.

Nerbonne JM, Gurney AM (1989) Development of excitable membrane properties in mammalian sympathetic neurons. J Neurosci 9: $3272-3286$.

Nerbonne JM, Gurney AM, Rayburn HB (1986) Development of the fast, transicnt outward $\mathrm{K}^{+}$current in cmbryonic sympathetic neurones. Brain Res 378:197-202.

O'Brien RJ, Fischbach GD (1986a) Isolation of embryonic motoneurons and their survival in vitro. $J$ Neurosci 6:3265-3274.

O'Brien RJ, Fischbach GD (1986b) Characterization of excitatory amino acid receptors expressed by embryonic chick motoneurons in vitro. J Neurosci 6:3275-3283.

O'Brien RJ, Fischbach GD (1986c) Excitatory synaptic transmission between interneurons and motoneurons in chick spinal cord cultures. J Neurosci 6:3284-3289.

O'Brien RJ, Fischbach GD (1986d) Modulation of embryonic chick motoneuron glutamate sensitivity by interneurons and agonists. J Neurosci 6:3290-3296.

O'Dowd DK, Ribera AB, Spitzer NC (1988) Development of voltagedependent calcium, sodium, and potassium currents in Xenopus spinal neurons. J Neurosci 8:792-805.

Oppenheim RW, Núñez R (1982) Electrical stimulation of hindlimb increases neuronal cell death in the chick embryo. Nature 295:5759.

Pittman RN, Oppenheim RW (1978) Neuromuscular blockade increases motoneurone survival during normal cell death in the chick embryo. Nature 271:364-366.

Pittman RN, Oppenheim RW (1979) Cell death of motoneurons in the chick embryo spinal cord, V. Evidence that a functional neuromuscular interaction is involved in the regulation of naturally occurring cell death and the stabilizing of synapses. J Comp Neurol 187 $425-446$

Purves D (1988) Body and brain: a trophic theory of neural connections Boston: Harvard UP.

Ribera AB, Spitzer NC (1990) Differentiation of $I_{K_{a}}$ in amphibian spinal neurons. J Neurosci 10:1886-1891.

Rogawski MA (1985) The A-current: how ubiquitous a feature of excitable cells is it? Trends in Neurosci 8:214-219.

Sakmann B, Neher E (1984) Patch clamp techniques for studying ionic channels in excitable membranes. Annu Rev Physiol 46:455-472.

Salkoff L, Wyman R (1981) Outward currents in developing Drosophila flight muscle. Science 212:461-463.

Schwindt PC, Crill WE (1984) Membrane properties of cat spinal motoneurons. In: Handbook of the spinal cord, anatomy and physiology (Vols 2, 3) (Davidoff RA, ed), pp 199-242. New York: Marcel Dekker.

Spitzer NC (1985) The control of development of neuronal excitability. In: Molecular bases of neural development (Edelman GM, Gall WE, Cowan WM, eds), pp 67-88. Neurosciences Research Foundation. New York: Rockefeller University Press.

Srihari T, Vrbová G (1978) The role of muscle activity in the differentiation of neuromuscular junctions in slow and fast chick muscles. J Neurocytol 7:529-540.

Weiss RE, Horn R (1986) Functional differences between two classes of sodium channels in developing rat skeletal muscle. Science 233: 361-364.

Yool AJ, Dionne VE, Gruol DL (1988) Developmental changes in $\mathrm{K}^{+}$-selective channel activity during differentiation of the Purkinje neuron in culture. J Neurosci 8:1971-1980.

Ziskind-Conhaim L (1988) Electrical properties of motoneurons in the spinal cord of rat embryos. Devel Biol 128:21-29. 